\title{
Carl Stumpf's Debt to Hermann Lotze
}

\author{
Nikolay Milkov (University of Paderborn)
}

\section{1. 'Stumpf, who will save you from Brentano?'}

Carl Stumpf (1848-1937) is a key figure in the fin de siècle germanophone philosophy. Unfortunately, after the World War One, the interest towards Stumpf as a philosopher waned. One of the reasons was that already in the 1920s the attention of the mainstream philosophers shifted in direction of the rising rivalry between analytic and continental philosophy. The authors of Stumpf's Festshrift of 1923 were mainly psychologists from the Berlin Institute of Psychology, grounded by Stumpf in 1906.

The interest towards Carl Stumpf's philosophy was revived only in the last twenty years or so. Great service in this provided the NeoBrentanists. ${ }^{1}$ But while the association of Carl Stumpf with Franz Brentano fostered Stumpf studies, it also gave rise of one-sided interpretations of Stumpf as a philosopher. In this way his importance and idiosyncrasy as philosopher remained in shadow. In this connection it deserves notice that before the World War Two, Carl Stumpf was considered an autonomous philosophically oriented psychologist, not simply another member of Franz Brentano's school. (Moog 1922, 157-61; Lehmann 1943, 107-13)

One of the objectives of this paper is to free Stumpf from Brentano: to try to see him as an autonomous philosopher. There is no better means for achieving this aim than the study of the relatedness between Carl Stumpf and his PhD and Habilitation Thesis supervisor Herman Lotze-Stumpf received his $\mathrm{PhD}$ in 1868, and his Habilitation in 1870 — at the University of Göttingen. Between 1870 and 1873 Stumpf was also an Adjunct Professor (Privatdozent) at that University where Lotze was a distinguished Professor. Soon Lotze became his 'devoted fatherly adviser' $(1917,5)$. The professor and his student

\footnotetext{
${ }^{1}$ Carl Stumpf Society was founded only in 2010. Cf. http://www.carl-stumpf.de/
} 
were so closely befriended that in 1869 Lotze seriously contemplated the possibility to visit Stumpf in Würzburg or Aschaffenburg during the summer vacation. (Lotze 2003, 541) Small wander, therefore, that Stumpf's first book Über den psychologischen Ursprung der Raumvorstellung (1873), that was praised by such figures like William James and Bertrand Russell, was dedicated to Lotze.

But it was not only Lotze that helped Stumpf to distance himself from his teacher and inspiration Franz Brentano. In Selbstdarstellung Stumpf also remembered that his real interest in sciences developed first in Göttingen where he also studied physics under Friedrich Kohlrausch and Wilhelm Weber. Together with the mathematician Felix Klein, Stumpf founded the 'Eskimo Society' of young scientists that read papers in different academic disciplines-Stumpf presented the position of philosophy. $(1924,8)$ In these years Stumpf also stroke up acquaintanceship with Leipzig psychophysics Fechner and E. H. Weber.

Of course, Stumpf was explicit that Franz Brentano played a central role in his philosophical development. Later Stumpf remembered:

My whole understanding of philosophy, the correct and mistaken methods of philosophizing, the basic and essential doctrines of logic and epistemology, psychology, ethics and metaphysics, which I still maintain today, are his doctrines. $(1919,144)$

But he also noted that '[Lotze's] way of thinking had influenced my thinking more than Brentano wanted it to be the case, despite the fact that the outline of my epistemology remained that of Brentano.' (Stumpf 1924, 4-5) Finally, Stumpf was also cautious enough to note that 'in general, such questions of property can be better judged by third parties, since those who do not pertain to the family can easily to discern family resemblances.' $(1919,144)$

This, exactly, will be our task in this paper: We shall try to outline which parts of Carl Stumpf's philosophy were developed under Brentano's influence and which parts under Lotze's, profiting from the distance in time.

\section{Zeitgeist}

Traditionally, philosophers are classified according to the countries in which they were born, received their education and made academic career. But it can be also insightful to group together philosophers that were born in the same year. If we follow this approach, we shall see that many influential European philosophers were born in 
1848: the year of sweeping political revolutions all over Europe, in Germany, in particular. Besides Carl Stumpf, in that year were also born Gottlob Frege, Wilhelm Windelband, Hermann Diels, Johannes Rehmke and Johannes Volkelt, in Germany, Arthur Balfour and Bernard Bosanquet, in the United Kingdom. The question arises: what shaped the philosophical formation of this group of philosophers?

Our guess is that it was the outstanding figure of Hermann Lotze. In 1864 Lotze published the third volume of his Microcosms, the first two volumes being issued in 1856 and 1858, respectively, which made him one of the most established philosophers of the time worldwide. At least four of our authors, Windelband, Frege, Stumpf, and Bonsanquet, were clearly influenced by Lotze: Windelband was his closest follower, Frege discussed Lotze's 'greater' Logik in his '17 Key Sentences to Logic', and Bosanquet was instrumental by the translation of the same book of Lotze and also of his 'greater' Metaphysics into English (1885-6) (Milkov 2010). The present paper will also show that Lotze also considerably influenced Carl Stumpf.

Of course, there were also other philosophers of the time that set up the character of philosophers born in 1848. One of them was Lotze's oldest ally in the fight against subjectivist in philosophy, Adolf Trendelenburg. Another figure of the same époque was Otto Liebmann, a former student of Lotze, whose famous book Kant und die Epigonen (1865) gave birth to the movement of Neo-Kantianism.

A legion of other scientifically oriented philosophers also inspired and educated the generation 1848: Fries, Herbart, and Fechner, among others. This point speaks against the claim that 'the years from 1830 to 1870 circa were a period of a crisis and decline for philosophy in Germany.' (Libardi 1996, 31) Exactly the opposite: between 1840 and 1870 German philosophy was on the rise: it prepared the Renaissance of philosophy that Stumpf speaks about in his 1907 inaugural address as a Rector of the University of Berlin. The historical mission of the generation 1848 was that it realized (materialized) its achievements. Unfortunately, many of these developments remained in shadow till today.

\section{Historical Context of the Introduction of the Concept of Inten- tionality by Brentano}

In order to correctly appreciate the respective influence of Brentano and Lotze on Carl Stumpf, we are first to investigate the relatedness of Lotze and Brentano as philosophers. There are both differences and affinities between them. 
Some authors claim that 'there was, to be sure, great mutual respect between Brentano and Lotze, as indicated by the fact that Brentano sent two of his pupils, ${ }^{2}$ Anton Marty and Carl Stumpf, to study with Lotze and also by the fact that Lotze played an important role in Brentano's call at the University of Vienna in 1874.' (Rollinger, 2001 112)

In truth, we can scarcely speak about symmetry in the relationship between Lotze and Brentano; neither was their relation simply a matter of mutual respect. Without any doubt, Lotze appreciated Brentano as a rising star of German philosophy. This is clear from the fact that he was instrumental in Brentano's instatement as professional philosopher. This fact, however, is not to be overestimated. The criteria that guided Lotze to support young philosophers were three: 'Has the person the knowledge that is a necessary in philosophy today; does he also has a command of the scientific methods; and is he deadly serious with his philosophical interests? Lotze recommended Brentano, starting from these standpoints', no more than that. (Baumann 1909, 179) Furthermore, when in June 1872 Brentano and Stumpf visited Lotze in his home near Göttingen (for some reasons, all called it 'the cafe grinder'), 'Lotze was friendly but discreet [schweigsam], as he often was.' (p. 125) Apparently, Brentano's visit to Lotze in his home was of no extraordinary importance for the latter.

In short, while Brentano learned much from Lotze, Lotze scarcely learned anything from Brentano. To be sure, Lotze was 21 years older than Brentano and started early his career so that (as we already have mentioned) he was well-established philosopher much before Brentano habilitated in 1866. This point was already noted in the literature: '[Trendelenburg and Lotze] are also ... Brentano's teachers. The historical-philosophical importance of Brentano consists in that he had revealed in an exemplary way the strength of these influences in the full variety of their forms.' (Orth 1997, 18) To remind the reader, Brentano's first publication on Aristotle in 1862, that was also his $\mathrm{PhD}$ Thesis (Brentano 1862), was dedicated to Trendelenburg.

Also Brentano's most distinguished achievement-the (re)introduction of the concept of intentionality in philosophy-was prepared by Adolf Trendelenburg and Hermann Lotze-above all, by the concept of experienced consciousness that has a process character. 'Decisive [at that] is the thesis about the absolute difference between psy-

\footnotetext{
${ }^{2}$ In fact, there were at least three: Brentano also sent his pupil Johannes Wolff to study with Lotze. $(1919,103)$
} 
chical and physical appearances and about the primacy of the psychical phenomena over the physical.' (Orth 1997, 24)

Two further points are of importance in this respect: (i) Lotze considered the concept of mind as a 'phenomenological expression'. (ibid., $21 \mathrm{f}$.) We have no singular referents for the soul but varieties of psychical phenomena that are to be described. In this sense Lotze also used the term 'descriptive (or empirical) psychology'. (ii) The presupposition of the intentionality are satisfied by Lotze's conception of substance as an entity 'that is capable to effect and to suffer.' (1879, 481)

This whole story shows that Brentano was not a 'lonely genius' that advanced his philosophy in complete isolation. In this respect the attitude of the Neo-Brentanists towards the source of their inspiration, Franz Brentano, is related to the attitude of the Neo-Fregeans, such like Michael Dummett, towards Gottlob Frege. Both believed that Brentano, resp. Frege, were solitary thinkers.

Even the picture of Brentano, drawn by some more objective historians:

Brentano's philosophy is part of the Aristotelian Renaissance which began with Bonitz's, Tricot's and Schwegler's works on Aristotle, and continued with Trendelenburg's Geschichte der Kategorienlehre. (Libardi 1996, 26)

is incomplete. In fact, the Aristotelian Renaissance itself was part and parcel of a massive movement against Kant's formalism that was started in Germany by Friedrich Schleiermacher and was continued by such philosophers and logicians like Trendelenburg, Lotze and also Frege. The latter, in particular, insisted that his logic, in contrast to that of George Boole, is not formal but logic of content.

\section{Further Points on which Lotze Preceded Brentano}

But there were also three other points on which the ideas of Lotze and Brentano were related. Of course, we are not going to explore their genealogical connection since this task goes beyond the scope of our study. We only insist that whereas some authors uncritically maintain that these ideas were introduced in philosophy by Franz Brentano, in fact, they were set up, perhaps in somewhat different form, by Hermann Lotze much before him.

(i) Priority of Judgment in Mental Life.Similarly to Brentano 20 years later, Lotze radically increased the role of judgment in our mental life. While Kant classified our mental abilities into (i) knowledge, 
(ii) sentiment, and (iii) desire, Lotze discriminated between (i) knowledge, (ii) judgment, and (iii) will. Brentano, on his side, adopted from Aristotle the classification of mental states into (i) presentation, (ii) judgments, and (iii) feeling.

Lotze, in particular, insisted that judgment is not an association of two presentations. In this, he opposed the British empiricists Hume and Mill. To Stumpf, too, the judgment plays a prime role in of our perception of sounds, colours and spaces; and also in our emotions and volitions.

(ii) Content of Mind. Lotze also introduced the concept of 'content'-both of experience and of judgment. The content of our experience are the perceptual data of our knowledge; the content of judgments are the states of affairs. ${ }^{3}$ (Milkov 2002) Among other things, the concept of the content of perceptions gave rise to the concept of sense-data. The latter was developed under Lotze's influence first by Josiah Royce (Royce was one year long Lotze's student in Göttingen), and then by William James; much later this concept was adopted by the founding fathers of analytic philosophy G. E. Moore and Bertrand Russell. (Milkov 2001) This story shows, among other things, how Lotze's ideas, that are clearly related to that of Brentano, also found resonance in other philosophical traditions that have little to do with Brentano.

(iii) Objectivism. Much before Brentano, Lotze stopped to explore the subject-object opposition, put at the centre of philosophy by Kant. Instead, he directed his attention to the order that is characteristic of both matter and mind. Especially important place in Lotze's theory of order played the concept of relation. He used to repeat: 'it belongs to the notion and nature of existence to be related.' (Lotze 1885, ii. 587) Beatrice Centi is right when she maintains that, according to Lotze, to think means to relate: for him, space is an 'inter-related seriality'. (Centi, p. 72) This, however, does not mean that Lotze never spoke about individuals. Indeed, what is related are individuals contents of perception. In other words, Lotze's relationism presupposes ontology of individuals.

5. Relatedness and Divergence Between Brentano, Lotze and Stumpf: Descriptive Psychology

Stumpf himself maintained that 'Lotze's views concur with those of Brentano only very partly [sehr teilweise].' (Brentano1919, 102)

\footnotetext{
${ }^{3}$ Cf. § 8, (ii).
} 
Negative as this statement is, it makes clear that on some points, at least, the positions of Lotze and Brentano coincide.

The general point on which Lotze, Brentano and Stumpf agree is that philosophy is a part of science: it is a very general science. It thus forms a continuum with science. ${ }^{4}$ As Stumpf put it, philosophy is 'after-science' (Nachwissenschaft); it investigates the common laws of all sciences. It is a theory of the world (Welttheorie). (1906, 43)

In more specific terms, Stumpf held that both Lotze and Brentano explored 'structural characteristics of mental functions'. ${ }^{5}(1924,46)$ The point is that in the realm of appearances, there are such things as 'immanent laws of structure' that are rather different from the causal laws - the latter are not valid in this realm. $(1906,28)$

But which were these 'laws of structure'? They were mainly of two types: those explored by the descriptive psychology, and those explored by, what we shall call, 'philosophical logic'. We are going to discuss the former in the lines of this section bellow, and the latter in $\S$ 6.

Following Brentano, Stumpf severely criticized to Kant's formalism. Kant's discrimination between form and qualia was not made through psychological discussion but through void metaphysical deliberations. But 'nothing can be epistemologically true and psychologically false.' (1891, 482) That is why Kant's criticism was harmful for the development of both philosophy and psychology. Indeed, space, time and causality, declared by Kant a priori forms of human reason, are nothing but contents of consciousness, everyone with specific multiplicity. (Ibid., 485)

Historically, Brentano opposed Kant following some ideas of Aristotle. ${ }^{6}$ Roughly, while Kant was more of a constructivist philosopher, Brentano was a kind of monolithic philosopher. While Kant developed a particular 'predilection for constructions', Brentano and Stumpf tried to bring to light the 'things themselves'. To be more exact, Brentano introduced the discipline of descriptive psychology as a Cartesian science in an effort to provide sound foundations for the whole phi-

\footnotetext{
${ }^{4}$ A thesis later revived by Quine.

${ }^{5}$ In his William James book, Stumpf identifies 'Lotze and Brentano [as] the great masters of analytic psycholohy and introspection'. (1928b, 28)

${ }^{6}$ Ultimately, Brentano's move paralleled Leibniz's turn back to Aristotle (in Leibniz's case, to Aristotle's 'substantial forms') as a means against the radically mechanical philosophy of Locke and Descartes.
} 
losophy. Its task is to reveal and describe the building blocks of both science and philosophy.

It deserves notice that while descriptive psychology was the discipline of Brentano and his school Lotze, in fact, practiced it for decades. More especially, his analysis of the content of perception was, in fact, a form of descriptive psychology. Brentano insisted that description is prior to explanation and to genetic psychology in general, 'which seeks to find the laws of mental event as unfolding in time' (Smith 1994, 27). But the very distinction between 'genetic' and 'descriptive' science was introduced by Lotze who strongly discriminated between the given, or what is, what happens, e.g. what changes (i.e. what is 'genetic'), and what is valid.

It deserves notice that following the physiologist Ewald Hering, Carl Sumpf called the descriptive psychology nativist: it explores the origin of our mental states: 'Nativists are called those [scientists] who assume the initial [Ursprüngliche], [and] empiricists, those who embrace genetic explanations.' $(1883,96)$ In other words, Stumpf identified 'empirical psychology' with 'genetic psychology'. Brentano, in contrast, understood descriptive psychology as empiricist psychology.

For our study, it is of special importance that both Lotze and Stumpf combined nativism and experimental psychology. In other words, in contrast to Brentano, Stumpf was both a descriptive psychologist and at the same time external (non-introspective) experiential psychologist, who checked the results he achieved in his nativist descriptions with experiments, without, however, to commit a 'genetic fallacy': without to become a genetic psychologist. Brentano's psychology, in contrast, 'was empirical [not in Stumpf's sense] without being experimental.’ (Libardi 1996, 36)

In fact, he advanced a new kind of empiricism that can be also called 'introspective empiricism'. Furthermore, exactly like Lotze, Stumpf was not only a philosopher but also a scientist. In contrast, despite the fact that in his Dissertation Brentano declared that 'the true method of philosophy is none other than that of the natural science' (Thesis iv), he never did 'real science'. (Ewen 2008, 21) In particular, Brentano was never occupied with psychological experiments, preferring instead to make armchair introspective psychological research.

In this connection, it deserves notice that in his Address to the Berlin University as its Rector in 1907, 'The Renaissance of Philosophy', Stumpf repeatedly referred to Fechner and Lotze as his predecessors,

\footnotetext{
${ }^{7}$ Among other things, this point found expression in Brentano's negative attitude to
} the Theory of Relativity—-he found it 'incoherent'. 
not to Brentano. The short hegemony of the idealistic systems in Germany ended with a catastrophe: they became obsolete already in the 1840s. In the 1850s and 1860s, Fechner and Lotze came on the scene, developing a bottom-up philosophy that starts from the sciences and verified their philosophical statements with the new scientific discoveries and theories. Some authors explain this statement of Stumpf with the 'confessional biases of that epoch' in Germany, having in mind that he read his address at the Prussian-and protestant-Berlin University. (Münch 2006, 57 n. 21) In truth, it refers to a serious difference between Carl Stumpf's and Franz Brentano's philosophy. ${ }^{8}$

Apparently, 'Stumpf had a drastically different idea of what scientific methodology actually is. Unlike Brentano, he left no place for any prominence of inner perception and its alleged evidence.' (Martinelli 2006, 82) This gave Ricardo Martinelli reasons enough to call him an empiricist. ${ }^{9}$ As we already have seen, however, Carl Stumpf understood himself as a nativist, not as an empiricist. But what Stumpf meant when he criticised empiricism was, in fact, the 'genetic' approach in psychology, practised by such colleagues of his like Wilhelm Wundt.

Finally, we are to also mention a point on which Brentano openly criticised Lotze. Above all, it was the theory of local signs of the latter which explains the relation between mind and matter in terms of our perception of space and movement. According to Lotze, what we directly see when perceiving a movement are only patches of colour. What helps us to perceive the fact of movement is the effort that we ourselves make in perceiving the movement. Lotze calls this stimulus a "local-sign." It is a means of transforming sense-perceptions into space-values. (Milkov 2010, § 3(e))

Stumpf joined Brentano in this critic. Apparently, Brentano and Stumpf were against the increased role of the free will in judgment that Lotze's theory introduced. In other words, they were against the involvement of a conscious, will-informed action that constitutes our reality. It deserves notice that Lotze embraced this theory following an idea of J. G. Fichte. In other words, it was a trace of the German Idealism in his philosophy-a trace that both Brentano and Stumpf felt to be alien to their objectivist intuitions.

\footnotetext{
${ }^{8}$ We shall address this point again in $\S 9$.

${ }^{9}$ The same does Schuhmann (2000/1), $63 \mathrm{ff}$.
} 


\section{From Strict Analytic Method to Philosophical Logic}

The extensive use of experimental methods in descriptive psychology was only possible because both Lotze and Stumpf took an idiosyncratic analytic method as starting point of descriptive psychology. Of course, Brentano's descriptive psychology was also analytic psychology. ${ }^{10}$ Following further ideas of Lotze, however, Stumpf added to it important new elements. Most importantly, Stumpf insisted that psychological analysis is possible in two ways: (i) through inner observations; (ii) through outer observations and experiments. $(1879,5)$ We can add to this that the former method was mainly followed by Brentano, the latter mainly by Stumpf.

In short, Stumpf's analytic psychology held that

through analysis [Zergliederung] of 'impressions', we reach the ultimate elements of concepts that we use in the ordinary thinking; elements that in the scientific thinking are combined in different ways, according to their needs. $(1891,491)$

In contrast, Kant was not interested in the origin of space, time and causality but in what these concepts contribute to the scientific discourse. Besides, Kant's failed to analyse his 'intuitions', so they remain complex ideas. Space, for example, is perceived through different senses that grasp different parts of it: place, magnitude, etc.

Stumpf's final objective was to put to light the 'absolute contents' of our mind, especially of our ideas of space and time. In this connection, he argued against the conception of relativity of perception, defended by Fechner, among others. According to the latter, every perception receives its meaning through connection with other perceptions. In contrast, Stumpf held that tones, smells, colors, and tastes, are sums of absolute qualities. $(1883,137)$

Furthermore, Stumpf explored the psychological origins (Ursprunge) of our ideas by way of analysis of complex ideas to their constituents. Important point is that the complex is not just a sum; but it is also not an 'organic unity'. The relation between complexes and elements is a relation between parts and whole. And there are parts that are independent from the whole, and there also parts that are ontologically dependent on them.

We shall call this type of philosophical analysis 'philosophical logic'. It presents an alternative way of disclosing immanent laws of

\footnotetext{
${ }^{10}$ Cf. George Stout’s Analytic Psychology (Stout 1886) written under Brentano’s
} influence. 
structure to that of the descriptive psychology. The exploration of philosophical logic was another debt of Stumpf to Hermann Lotze. Prime example of Lotze's philosophical logic was his method of recasting specific problems of German Idealism in a refined, logical form. A typical example was his approach to studying thinking. Lotze connected thinking to two 'logically different' domains, valuing and becoming, and considered each of them to be explored by a special science: logic investigates the validity of thinking, and (genetic) psychology investigates the development of thinking.

Typical discovery of Stumpf in philosophical logic was that a kind of space is already given with the idea of quality: we cannot imagine space without a colour, neither a colour without space. This idea of Stumpf profoundly influenced Edmund Husserl's theory of 'grounding' (fundieren): there are concepts that exist autonomously, and other kind of concepts that are ontologically dependent on the autonomous concepts. Husserl himself loudly acknowledged his debt to Stumpf on this point, ${ }^{11}$ a point that was unknown to Brentano. (Husserl 1901).

At the end of this section we would like to point out that Stumpf's analytic psychology was unexpectedly close to some leading ideas of the founding fathers of analytic philosophy. Above all, the program for investigating 'absolute contents', as developed in Tonpsychologie (1883-1890), was closely related to the ontology of Russell's logical atomism. ${ }^{12}$ Besides, Stumpf's conception of judgment was very close to that of Frege as developed in his famous paper 'On Sense and Reference'. Indeed, Stumpf was explicit that judgment plays a central role not only in the art or in politics, 'but already in the most elementary spontaneous [unwillkürlicher] comprehension and interpretation of sense-impressions.' $(1899,5)$ It is active in every space orientation. A related position is defended in Tonpsychologie:

Judging, as we understand it, does not always consist in deliberations and is not always connected with language, even not with inner speech. In many situations it is immediately and instantly connected with sense impressions. $(1883,4)$

Similarly, Frege claimed that with every 'serious' thought we have when we are awake (i.e. not in a game, or in a daydream), for exam-

\footnotetext{
${ }^{11}$ Husserl did so even in the short Summary of his Logical Investigations, vol. 2, he himself composed. (Husserl 1901)

${ }^{12}$ One explanation of the fact that Stumpf's ontology is close to the analytic philosophy of Russell is the influence Hermann Lotze exercised on the early Russell. (Milkov 2008)
} 
ple, 'It's raining now!', we already judge a situation as true or false: 'the step from the level of thought to the level of reference (the objective) is already done [in it]'. ${ }^{13}$ (Frege 1892, 34)

\section{Further Points of Relatedness Between Lotze and Stumpf}

We have already noted that although Stumpf started his philosophical development as a devoted Brentanist, he gradually distanced himself from the theoretical position of his teacher-despite the fact that emotionally, he remained Brentano's loyal devotee. Furthermore, most of Stumpf's differences with Brentano were a result of his apprenticeship with Lotze. In the lines above we already have mentioned some specific ideas that Stumpf inherited from Lotze. In this section, we are going to add another three points of influence that can be only expressed in more general terms.

(i) Stumpf as Non-Dogmatic Philosopher. Similarly to Lotze, and in contrast to Franz Brentano, Carl Stumpf was not a dogmatic philosopher. He claimed that exactly like science, philosophy is to be a cooperative study and not just a matter of schools and sects. (1907, 194; Münch 2006, 14)

A good example of this stance, as developed by Lotze, was that even Stumpf's open criticism of his theory of logical signs didn't harm the personal friendship between teacher and student $(1917,5)$. Exactly the opposite was the attitude of Franz Brentano to his students. Prominent case was Stumpf's discussion with Brentano as to does pleasure have a content or not. More especially, Stumpf denied Brentano's position that sense perceptions (bodily pain, pleasure, etc.) have content. Content have only our emotions in form of particular states of affairs.

Stumpf's dispute with Brentano on emotions had disastrous consequences:

[Brentano] blamed Stumpf in a bitter tone for his deviations from the original doctrine, and suggested, as wrote Stumpf in his preface,

\footnotetext{
${ }^{13}$ Some authors insist, referring to Paul Linke (1876-1955), that 'many of Frege's theories had been developed within Brentano's school.' (Hill 1998, 45) In fact, the otherwise enigmatic relatedness between Frege and Brentano's school can be comfortably explained with Frege's relatedness to Lotze's logic which is an established fact. (Gabriel 1989) If we connect this point with Lotze's relatedness to Brentano we have already said much about above, then the genealogical circle of influence gets closed. Parts of Frege's logic show relatedness to Brentano and his school since both Brentano and Frege adopted vital ideas of Hermann Lotze.
} 
'that I seemed to be a dissident for him'.... There followed a long controversy in the correspondence and in a series of published papers, which lasted until Brentano's death in 1917. (Fisette 2011, 401)

The effect of this attitude of his teacher was clearly negative for Stumpf's intellectual development. Above all, it narrowed the scope of his philosophical explorations. Later Stumpf remembered:

I admit that this was one of my motives for developing a considerable amount of time to the area of the psychology of sound and acoustical observation. There I could hope to achieve something useful without taking a position of agreement or dissent with regard to a great number of unpublished views of the teacher. It was the same with Marty in philosophy of language and Kraus in philosophy of law. $(1919,145)$

(ii) Stumpf Didn't Ground His Own Philosophical School. One upshot of Lotze's theoretical liberalist was that he didn't found his own philosophical school. This was out of question exactly because of the 'exceptional considerate liberality [of Lotze] in relation to every personal development. The individual person was for him an untouchable sanctity.' $(1917,10)$ In a radical contrast with Brentano, Lotze instructed his readers to regard his philosophy as 'an open market, where the reader may simply pass by the goods he does not want' (Lotze 1874, p. 4).

Similarly to Lotze and in contrast to Brentano, Stumpf never set up a school of philosophers, despite the fact that among his pupils there were such prominent figures like Edmund Husserl, Wolfgang Köhler and Kurt Lewin. ${ }^{14}$ (To some extent, Stumpf can be only considered the father of the school of Gestalt-psychology.) Apparently, this was also the main reason why Stumpf, the philosopher, was delivered to oblivion for decades - a fate he shared with his teacher in philosophy Hermann Lotze.

We further maintain that the difference in method of teaching, dogmatic or liberal, was not simply a William Jamesian matter of temperament. It reflects the difference in the philosophical method employed by Brentano, on the one hand, and Lotze-Stumpf, on the other hand. While the philosophy of Brentano was more of deductive and synoptic, the philosophy of Lotze-Stumpf was supposed to be led by empirical research-it so proceeded bottom-up, and was developed

\footnotetext{
${ }^{14}$ We are going to discuss Wolfgang Köhler and Kurt Lewin as philosophers in § 9.
} 
step-by-step, pecemeal. Stumpf himself maintained that '[Brentano's] advantage was in the deductive part of the [nativist] method, in the set-up of most general perspectives.' $(1919,147)$

It cannot be a surprise, therefore, that Brentano was close to other deductive philosophers, like Husserl and Frege, also in another respect: he was dogmatic in regard of any further elaboration of his philosophy. Closer to Lotze-Stumpf, in contrast, were some empirically oriented philosophers, such like Russell and Carnap, who practiced an 'open door policy', encouraging correction of their own philosophy through their students. (Milkov 2012)

(iii) Theoretical Persistency. Finally, Lotze and Stumpf were also related in that they both didn't radically change their position in philosophy. In contrast, Brentano's philosophy has its Part One and Part Two: while the early Brentano was a descriptive psychologist, in his second, ontologically-oriented phase, he developed an idiosyncratic philosophy of reism.

\section{The Concepts of Space and State of Affairs}

Important characteristic of Carl Stumpf as a philosopher was that he inherited Lotze's interest in the external world: a stance that put space, time and numbers at centre of his philosophy. Among other things, this point is supported by the fact that in his Göttingen years (1868-1873), Stumpf was also on good terms with the philosopher Julius Baumann, to which exactly the concepts of space, time and numbers were of prime importance. ${ }^{15}$ Unfortunately, Stumpf didn't develop his ontological interests in full. As a young philosopher, he was seriously working in theory of numbers and even wrote his Habilitation Thesis on this subject. (1870) Still in Göttingen, however, his friend Felix Klein convinced him that new developments in mathematics made his position inconsistent. In consequence, Stumpf decided not to publish it. As regards Stumpf's philosophy of time, apparently, he was hampered to develop it because of the paralyzing effect of Brentano on his students we already spoke about: indeed, Brentano himself worked on psychology of time perception.

Be this as it can, the only area in which Stumpf developed his ontological intuitions in full were the problems of space and state of affairs.

\footnotetext{
${ }^{15}$ Baumann's Die Lehren von Raum, Zeit und Mathematik in der neueren Philosophie (1869) was the book which Frege most often referred to in his Grundlagen der Arithmetik (1884): it was Frege's main source of historical information in philosophy of arithmetic.
} 
(i) Space. Similarly to Kant, Lotze held that space and time are forms of intuition that make our knowledge possible. In contrast to Kant, however, he discriminated between extension and place / moment. Extension is a conceptual (formal) notion and refers to an infinite multiplicity of possible directions. Only a place in space or a moment in time, however, makes them reality. ${ }^{16}$ With this conception, Lotze tried to preserve the objective character of space and time, opposing in this way Kant's subjectivism.

Stumpf developed Lotze's objective conception of space and time further into the idea that the places and moments are perceptual contents (Sinnesinhalte). These are psychological phenomena. 'A perceived space is not composed of many identical impressions, but a unity in which we can discern [through analysis] different parts.' $(1873,126)$ Moreover, the order is ontologically dependent on content: indeed, 'there is no order which is not based on an absolute content.' (Ibid., 275)

(ii) States of Affairs.Following Smith (1992) and also Stumpf himself, many philosophers today maintain that the concept of states of affairs was introduced in Stumpf's manuscript lectures on logic (1888). Beatrice Centi had recently added to this that Stumpf also 'uses the term Sachverhalt before the year 1888, in a less technical but not less significant sense due to its generality, in the same way as he uses the term series.' (Centi, p. 77) More especially, Stumpf's concept of states of affairs as the concept of judgment was 'rooted in a wider concept of state of affairs expressing the intrinsic and totally subjectindependent relationality of reality.' (Ibid., p. 78) Indeed, Stumpf constantly explored how do contents relate to one another: 'how does space and quality relate to one another [sich zueinander verhalten]? ${ }^{17}$ $(1873,107,114)$ This was actually the tenor of the Raumbuch.

In fact, however, the use of the concept of state of affairs in the Raumbuch, which Centi refers to in support of her claim, is neither in the sense of content of judgment, nor in the sense of contents related to one another. Rather, it is used in the trivial sense of a case (casus) that is also popular in the ordinary German today, especially in the legal discourse. In contrast, in his 'great' Logic (1874), i.e. much before 1888, Lotze repeatedly refers to the concept of states of affairs in

\footnotetext{
${ }^{16}$ Among other things, this position deeply influenced Bertrand Russell's philosophy of space and time. (Milkov 2008)

${ }^{17}$ This is also a part of Wittgenstein conception of states of affairs advanced in the Tractatus: 'In states of affairs the objects are combined in a definite way [verhalten sich die Gegenstände ... zueinander].' (2.031)
} 
the sense of content of judgment. (Milkov 2002) The Neo-Brentanists are reluctant to recognize this fact because they fail to realize that already Lotze introduced the concept of content of judgment as well as of the content of perception in philosophy. ${ }^{18}$ Otherwise, it is really the case that the concept of states of affairs is rooted in relativist ontology: in the relativist ontology of Lotze, however, which was developed much earlier and genealogically preceded that of Carl Stumpf. Indeed, Lotze spoke about contents that relate to one another already in his 'lesser' Logic. $(1843,25)$

\section{Carl Stumpf's Philosophical Acolytes}

Looking to Carl Stumpf as another member of the Brentano's School, some authors ask the question: 'was Stumpf, who received his repute as experimental psychologist, a philosopher at all'? (Münch 2006, 12) The author who poses this question, Dieter Münch, eventually answers it in positive. But the very fact that it was posed, says much about the state of Stumpf studies today.

One of the arguments for denying Stumpf the status of a philosopher is that, 'apparently, Stumpf lacks the philosophical ambition that characterizes Brentano and his school. He had neither Brentano's sense of mission, nor the relentless defending stance, typical for Marty, Kraus and other followers of Brentano.' (Ibid., 13) We consider this view radically mistaken. Stumpf had both strong philosophical interest, and also a clear philosophical message. These, however, didn't look in the direction of the mainstream Brentano's school members.

One of the reasons for denying Stumpf the status of philosopher is that, allegedly, he had just one philosophy pupil—Edmund Husserl. This claim is not true either. In fact, Stumpf also exerted a forming influence on the Berlin Group around Hans Reichenbach (1928-1933) and on the Society for Scientific Philosophy (1927-1935) that had program parallel to but at the same time clearly different from the program of the Vienna Circle. ${ }^{19}$

To be more exact, Stumpf influenced the Berlin Group mainly through his closest pupils, Kurt Lewin und Wolfgang Köhler, who were also members of the Board of the aforementioned Society. Lewin and Köhler also took part in the first Conference of Exact Philosophy in Erlangen in March 1923 and were instrumental by establishing

\footnotetext{
${ }^{18}$ Cf. § 3, (b).

${ }^{19}$ In short, while Vienna Circle defended logical positivism, the Berlin Group defended the philosophy of logical empiricism. (Milkov 2013)
} 
the Zeitschrift für exakte Philosophie in 1923 (the journal never appeared). (Milkov 2011, xiv) Later both of them contributed papers to the legendary journal of scientific philosophy Erkenntnis (1930-9). Köhler also acted as a reader of the Doctoral Theses of the core members of the Berlin Group Walter Dubislav and Carl Hempel. Besides, between 1920 and 1929 Hans Reichenbach and Paul Oppenheim worked close together with Kurt Lewin. Rudolf Carnap, in his The Logical Construction of the World, and Hans Reichenbach, in Philosophy of Space and Time (both 1928), made extensive use of Kurt Lewin's term of genidentity. (cf. Padovani 2013) Finally, another core member of the Berlin Group, Kurt Grelling, explored (partly together with Paul Oppenheim) the logical aspects of Gestalt theory.

That Carl Stumpf's philosophy is related to the scientific philosophy as developed in the second half of the twentieth century is also clear from a number of claims he made. We have already noted (in $\S$ 5) that Stumpf repeatedly spoke about the 'catastrophe' resulting from the supremacy of the philosophy of the German Idealism between 1790 and 1840. The 'Renaissance of philosophy', started up in the mid-nineteenth century, following the (re)introduction of special sciences, especially the introduction of psychology, into it.

Reading some of Stumpf's papers, one gets the impression that what Bertrand Russell and Hans Reichenbach later have called the 'rise of scientific philosophy', in fact already took place in the 1850s and 1860s in Germany thanks to such scientifically oriented philosophers like Fechner and Lotze. Both of them were not only philosophers but also scientists: Lotze was also a Professor of medicine and Fechner was also a physicist. This is how the rebirth of philosophy was realized. To Stumpf, it is important that 'philosophers learn and are trained in a specific craft [Handwerk] which means that they have to have experience in some concrete area of either humanities [Gesisteswissenschaften] or natural sciences.' $(1907,179)$ Only experts trained in this way can produce 'a philosophy which has an exact concept-formation and strict proofs.' (Ibid., 180) Precisely this way of working made Leibniz great philosopher also today. ${ }^{20}$

Most importantly, Carl Stumpf's program for renewal of philosophy was very close to that of Hans Reichenbach not only in the direction it followed but also in its content. Indeed, Stumpf advanced a kind of empirical philosophy (Erfahrungsphilosophie) that progresses

\footnotetext{
${ }^{20}$ Carl Stumpf started the German Leibniz Academic edition in 1923 writing for it an enthusiastic preface. (The edition is still not finished. Cf. http://www.leibnizedition.de/)
} 
step by step, and whose aim is to achieve a 'relative conclusion', ${ }^{21}$ so that 'every higher step [of science] conveys new life-impulses [to philosophy]'. (Stumpf 1907, 170) Similarly, according to Reichenbach, every significant scientific discovery and theory is to be logically explored in order to distill the constitutive principles of the renewed science. (Milkov 2011, ix)

In this connection it deserves notice that Reichenbach was Carl Stumpf's student at the University of Berlin. Apparently, Stumpf's lessons didn't remain without a trace for Reichenbach's formation as a philosopher. And the main reason why the relation between Stumpf and Reichenbach didn't develop in full form was ideological rather than theoretical. At the beginning of the twentieth century, Carl Stumpf was namely conceived of as an anti-social-revolutionary philosopher, while for Reichenbach the revolution in philosophy was part and parcel of the social revolution. (Milkov 2012, § 5) In more detail, being a Chancellor of the Berlin University, Stumpf was engaged in a conflict (he himself spoke of a 'war') with the left-wing 'free student movement' (cf. 1908); ultimately, he dissolved that society. Later the society was restored and, understandably, its members saw Stumpf as another old-fashioned 'bourgeois' philistine. At the beginning of the 1910s, Hans Reichenbach was a very engaged member of the freestudents movement and, by all accounts, adopted the negative attitude to his philosophy professor from the older fellow-students. It deserves also notice that psychologically, Reichenbach was very sensitive in respect of who supports his endeavors and who, he believed, was against them.

\footnotetext{
${ }^{21}$ Cf. with the concept of 'relative a priori' as developed in Friedman 2001. Friedman's main point of inspiration by elaborating this conception was the scientific philosophy of the early Hans Reichenbach.
} 


\section{References}

Baumann, Julius. 1869. Die Lehren von Raum, Zeit und Mathematik in der neueren Philosophie nach ihrem ganzen Einfluß dargestellt und beurteilt, Berlin: Reimer.

. 1909. 'Persönliche Erinnerungen an Hermann Lotze', in Annalen der Naturphilosophie 8: 175-182.

Bonacchi, Silvia and Boudewijnse, Geert-Jan (eds.). 2011. Carl Stumpf-From Philosophical Reflection to Interdisciplinary Scientific Investigation, Vienna: Krammer.

Brentano, Franz. 1862. Von der mannigfachen Bedeutung des Seienden nach Aristoteles. Freiburg: Herder.

Centi, Beatrice. 2011. 'Stumpf and Lotze on Space, Reality, Relation' in Bonacchi, Silvia and Boudewijnse, Geert-Jan (eds.): 69-81.

Ewen, Wolfgang. 2008. Carl Stumpf und Gottlob Frege. Würzburg: Königshausen \& Neumann.

Fisette, Denis. 2011. 'Love and Hate: Brentano and Stumpf on Emotions and Sense Feelings', in Bonacchi, Silvia and Boudewijnse, Geert-Jan (eds.): 37-49.

Frege, Gottlob. 1892. 'Über Sinn und Bedeutung', Zeitschrift für Philosophie und philosophische Kritik, NF 100: 25-50.

Friedman, Michael. 2001. Dynamics of Reason, Stanford.

Gabriel, Gottfried. 1989. 'Einleitung des Herausgebers: Objektivität, Logik und Erkenntnistheorie bei Lotze und Frege', in H. R. Lotze, Logik, Drittes Buch. Vom Erkennen (Methodologie), Hamburg: Meiner, xi-xxxiv.

Hill, Claire Ortiz. 1998. 'Introduction to Paul Linke’s [paper] “Gottlob Frege as Philosopher” ', in Roberto Poli (ed.), The Brentano Puzzle, Aldershot: Ashgate: $45-47$.

Husserl, Edmund.1901. 'Selbstanzeige: Logische Untersuchungen. Zweiter Teil', Vierteljahrsschrift für wissenschaftliche Philosophie 25: 260-3.

Libardi, Massimo. 1996. 'Franz Brentano (1838-1917)' in Arbertazzi, Liliana (ed.) The School of Franz Brentano. Dordrecht: Kluwer: 25-79.

Lehmann, Gerhardt. 1943. Die deutsche Philosophie der Gegenwart, Stuttgart: Kröner.

Lotze, Rudolf Hermann. 1843. Logik, Leipzig: Weidmann

—. 1874. Logik, Leipzig: Hirzel.

- 1879. Metaphysik: Leipzig: Hirzel.

- 1885. Microcosmus: An Essay Concerning Man and his Relation to the World, 2 vols., E. Hamilton and E. E. Constance Jones, Trans., Edinburgh: T. \& T. Clark.

—. (2003). Briefe und Dokumente, ed. by R. Pester, Würzburg: Königshausen \& Neumann.

Martinelli, Riccardo. 2006. 'Descriptive Empiricism: Stumpf on Sensation and Presentation' in Brentano Studien 10: 81-100.

Milkov, Nikolay. 2001. 'The History of Russell's Concepts "Sense-data” and "Knowledge by Acquaintance” , , Archiv für Begriffsgeschichte 43 (2001), pp. 221-31.

—. 2002. 'Lotze's Concept of "State of Affairs” and Its Critics' in Prima philosophia 15: 437-50.

- 2008. 'Russell's Debt to Lotze', Studies in History and Philosophy of Science, Part A, 39:2 (June 2008), pp. 186-93. 
2010. 'Rudolf Hermann Lotze’, Internet Encyclopedia of Philosophy. 2010. http://www.iep.utm.edu/lotze/

2011. 'Einleitung: Hans Reichenbachs wissenschaftliche Philosophie', in: Hans Reichenbach, 'Ziele und Wege der heutigen Naturphilosophie' und andere Schriften zur Wissenschaftstheorie, Herausgegeben, eingeleitet und mit Anmerkungen versehen von Nikolay Milkov, Hamburg: Felix Meiner: vii-xliv.

- 2012. "The Construction of the Logical World: Frege and Wittgenstein on Fixing Boundaries of Human Thought”, in: Elisabeth Nemeth et al. (eds.), Crossing Borders: Thinking (Across) Boundaries, Proceedings of the $9^{\text {th }}$ Congress of Austrian Philosophical Society, Vienna, 151-61.

- 2013. "The Berlin Group and the Vienna Circle: Affinities and Divergences", in: Milkov and Peckhaus (eds.). (to appear)

Milkov, Nikolay, and Peckhaus, Volker (eds.). 2013. The Berlin Group: Conference Proceedings, Dordrecht: Springer Verlag, Boston Studies Series (to appear).

Moog, Willy. 1922. Die deutsche Philosophie des 20. Jahrhunderts, Stuttgart: Enke.

Münch, Dieter. 2006. 'Erkenntnistheorie und Psychologie: Die wissenschaftliche Weltauffassung Carl Stumpfs' in Brentano Studien 10: 11-64.

Orth, Ernst Wolfgang. 1997. 'Metaphysische Implikationen der Intentionalität. Trendelenburg, Lotze, Brentano’ in Brentano Studien 7: 13-30.

Padovani, Flavia. 2013. 'Genidentity and Topology of Time: Kurt Lewin and Hans Reichenbach' in Milkov and Peckhaus (eds.), (to appear)

Rollinger, Robin. 2001. 'Lotze on the Sensory representation of space' in Albertazzi Liliana (ed.) The Dawn of Cognitive Science: Early European Contributors. Dordrecht: Kluwer: 103-122.

Schuhmann, Karl. 2000/2001. 'Stumpfs Vorstellungsbegriff in seiner Hallenser Zeit' in Brentano Studien 9: 63-88.

Smith, Barry. 1992. 'Sachverhalt', in Ritter J. and Gründer, K. (eds.), Historisches Wörterbuch der Philosophie, Basel: Schwabe, vol. 8, 1102-1113.

—. 1994. Austrian Philosophy: The Legacy of Franz Brentano, Chicago and La Salle (Ill.): Open Court.

Stout, George. 1886. Analytic Psychology. London: Allen \& Unwin.

Stumpf, Carl. 1870. Über die Grundsätze der Mathematik, Wolfgang Ewen's transcription of Stumpf's Habilitation. Würzburg: Königshausen \& Neumann, 2008.

- 1873. Über den psychologischen Ursprung der Raumvorstellung, Leipzig:

Hirzel.

1883. Tonpsychologie, vol. I, Leipzig: Hirzel.

1888. Logik. Karl Schuhmann’s transcription of the lithographed text Q13. Husserl Archive, Cologne.

1890. Tonpsychologie, vol. II, Leipzig: Hirzel.

1891. 'Psychologie und Erkenntnistheorie', Abhandlungen der bayerischen Akademie der Wissenschaften, Philosophisch-Philologische und Historische Klasse, 19: 465-516.

1899. 'Über den Begriff der Gemütsbewegung', in 1928a, 1-53.

—. 1906. 'Zur Einteilung der Wissenschaften', Abhandlungen der KöniglichPreußischen Akademie der Wissenschaften, Philosophisch-historische Klasse, Berlin: Verlag der Königliche Akademie der Wissenschaften, 1-94.

1907. 'Die Wiedergeburt der Philosophie', in 1910, 161-96.

1908. 'Vom ethischen Skeptizismus', in 1910, 161-96.

1910. Philosophische Reden und Vorträge, Leipzig: Barth.

- 1917. 'Zum Gedächnis Lotzes', Kant-Studien 22: 1-26. 
—. 1919. 'Erinnerungen an Franz Brentano', in Kraus, Oskar (ed.), Franz Brentano. Zur Kenntnis seines Lebens und seiner Lehre, München: Beck: 87-149.

1924. 'Selbstdarstellung' in Schmidt, Raymund (ed.), Die Philosophie der Gegenwart in Selbstdarstellungen, 5. Band. Leipzig: Meiner: 205-265.

—. 1928a. Gefühl und Gefühlsempfindung, Leipzig: Barth.

—. 1928b. William James nach seinen Briefen, Berlin: Pan Verlag. 